ISSN 1392-3196 / e-ISSN 2335-8947

Zemdirbyste-Agriculture, vol. 107, No. 1 (2020), p. 41-48

DOI $10.13080 /$ z-a.2020.107.006

\title{
Evaluation of agro-biological traits of Medicago sativa and $M$. varia in a Cambisol and Retisol
}

\author{
Aurelija LIATUKIENE ${ }^{1}$, Regina SKUODIENE², Donata TOMCHUK ${ }^{2}$, Vida DANYTE ${ }^{1}$ \\ ${ }^{1}$ Lithuanian Research Centre for Agriculture and Forestry, Institute of Agriculture \\ Instituto 1, Akademija, Kèdainiai distr., Lithuania \\ E-mail: aurelija.liatukiene@lammc.lt \\ ${ }^{2}$ Lithuanian Research Centre for Agriculture and Forestry, Vėžaičiai Branch \\ Gargždų 29, Vèžaičiai, Klaipèda distr., Lithuania
}

\begin{abstract}
Alfalfa (Medicago spp.) plays an important role in a farming system and contributes to stabilization of the ecosystem by improving soil physical, chemical and biological properties. However, the use of alfalfa is limited due to its susceptibility to edaphic conditions. The objective of this study was to evaluate the agro-biological traits of alfalfa under different soil conditions. Field experiments were carried out in two locations with optimised management. Agro-biological traits of 46 alfalfa (Medicago sativa L. and M. varia Marth.) accessions of different geographic origin were assessed in a high productivity Endocalcari Epigleyic Cambisol. Although environmental conditions were favourable for alfalfa development and growth, the tested genotypes significantly differed in agro-biological traits: plant height of regrowth in spring and after cuts and at flowering period as well as seed yield. Cultivars from colder climate countries (Estonia, Latvia and Lithuania) were the least affected by the downy mildew. In a low productivity acidic Bathygleyic Dystric Glossic Retisol, the $\mathrm{pH}$ had a major influence on the distribution of the root system of alfalfa-grass mixture. During the first experimental year, in the naturally highly acidic soil ( $\mathrm{pH}$ 3.9), where the mineral nutrition was unfavourable, alfalfa produced longer roots, their diameter and mass were larger than in the soil with a $\mathrm{pH}$ of 5.0. In the third year of cultivation, in the naturally highly acidic soil only $9.1 \%$ of alfalfa plants had survived. A strong correlation $(r=0.873, P<0.01)$ was determined between the amount of alfalfa in the dry matter yield and soil acidity.
\end{abstract}

Key words: alfalfa, agro-biological traits, different productivity soils, diseases.

\section{Introduction}

Alfalfa (Medicago spp.) is the largest cultivated forage crop in the world (Zeinab et al., 2014). It is grown for hay, silage and grazing as a valuable crop characterised by a high nutritional quality, abundant biomass production and broad adaptability to a wide range of cultivation conditions as well as by favourable impact on the environment. It exerts positive effects on soil fertility and structure and prevents soil erosion (Bouton, 2012; Sabanci et al., 2013). It is widely adaptable to diverse environmental conditions partly because of its deep root system and the ability to fix atmospheric nitrogen in symbiosis with Rhizobium meliloti. As a perennial plant, alfalfa is characterised by a wide genetic variation for adaption to specific growth conditions that can be exploited to widen substantially the adaption and utilization (Annicchiarico, Pagnotta, 2012).

Alfalfa mixtures with Poaceae grasses have an advantage over pure crops. Such mixtures form a good sward, more intensively restore soil structure, produce higher yield during droughts and compete better with weeds than pure alfalfa (Daugèlienè, 2010).
Soil acidity is one of the most important factors limiting crop production worldwide. It has been estimated that approximately $40.0 \%$ of arable land and $70.0 \%$ of nonagricultural soils in the world have a high level of acidity (Filiz, Meral, 2007; Dugalić et al., 2012). Acidic soils are often associated with a high concentration of aluminium (Al) ions.

According to the world distribution of acid soils, Lithuania falls into the northern belt in the cold humid temperate zone. Less productive soils - moraine loamy Retisols - in Lithuania account for about $8 \%$ of the country's total soil area. Retisols have a low buffering capacity and sorption, resulting in fast acidification, loss of nutrients and water reserves (Repšienè, Karčauskienė, 2016).

Acid soils are the major barrier to agricultural production due to the direct effects of $\mathrm{pH}$ on the root environment and plant growth (Tomchuk, 2018). Acidity restrains root growth and, consequently, the uptake of water and mineral nutrients. The top soil layer, containing more organic matter, is dominated by $\mathrm{H}^{+}$,

Please use the following format when citing the article:

Liatukiene A., Skuodiene R., Tomchuk D., Danyte V. 2020. Evaluation of agro-biological traits of Medicago sativa and M. varia in a Cambisol and Retisol. Zemdirbyste-Agriculture, 107 (1): 41-48. DOI 10.13080/z-a.2020.107.006 
while Al toxicity is more evident in the layer beneath. In an acid soil plants become stressed, and the state of stress becomes evident from such negative symptoms as slow growth, weak tillering, crop thinning, delay in various development stages and susceptibility to diseases (Goulding, 2016; Wang et al., 2016).

Alfalfa plants are subject to attacks of fungal diseases which affect survival of healthy plants causing considerable yield losses (Morsy et al., 2011). Root plasticity plays an important role in plant adaptation to heterogeneous environments. Plants exhibiting rapid and highly plastic responses in root growth and development may be at a selective advantage, because they can rapidly utilize the available resources. Although the relative importance of altered root morphology (density, length, hairs, etc.) vs uptake kinetics is still debatable, it seems clear that many plant species are capable of rapidly adjusting both their morphology and physiology in the acquisition of limiting essential resources that become available in a localized patch of soil (Huang, Eissenstat, 2013). Difference in root distribution is a factor influencing the extent to which plants are able to tolerate moisture stress, but it may also have beneficial effects on soil porosity delivering ecosystem services (Marshall et al., 2014).

Planting Al-tolerant cultivars in combination with liming is the most promising approach to improvement of alfalfa production on acid soils (Rahman et al., 2018). Avci et al. (2010) recorded significant differences among alfalfa lines and cultivars in dry matter yield and quality traits. Agro-morphological traits have been used to classify and study the genetic diversity in alfalfa germplasm collections (Tucak et al., 2014).

We hypothesized that in a high productivity Endocalcari Epigleyic Cambisol, where environmental conditions are favourable for alfalfa growth, the characteristics such as stem density, stem thickness, height, herbage yield and seed yield will be more pronounced. In a low productivity naturally acidic Bathygleyic Dystric Glossic Retisol, alfalfa development and agro-biological traits will be affected by soil $\mathrm{pH}$ and mobile Al content. The root mass will develop most intensively during the second year of growth of alfalfa and grass sward. More diverse uses of alfalfa and its mixtures in the soils of different acidity would be a precondition for the development of aluminous grasses in Lithuania.

The aim of this study was to evaluate the agrobiological traits of alfalfa in different soil conditions.

\section{Materials and methods}

Site and soil description and experimental design. Agro-biological traits of alfalfa (Medicago spp.) accessions were evaluated in the high productivity field (experiment I) of Lithuanian Research Centre for Agriculture and Forestry. Research was conducted at the Institute of Agriculture (in the central part of Lithuania, $55^{\circ} 23^{\prime} \mathrm{N}$ lat., $23^{\circ} 51^{\prime} \mathrm{E}$ long.) in the field of a six-course crop rotation of forage grasses in experimental years 2014-2017.

Cold and wet climate conditions prevail in the central region of Lithuania. The weather conditions of the experimental years were cold and wet in winter and very warm and humid in summer. During the study period, the average air temperature was $-4.4^{\circ} \mathrm{C}$ in January and $+18.0^{\circ} \mathrm{C}$ in July. The average annual precipitation was $591 \mathrm{~mm}$ in 2014 and $713 \mathrm{~mm}$ in 2017 (Table 1).

The soil of the experiment I site was Endocalcari Epigleyic Cambisol (WRB, 2014). Physico-chemical properties of soil: texture - light loam, $\mathrm{pH}$ 7.2-7.5, mobile $\mathrm{P}_{2} \mathrm{O}_{5} 201-270 \mathrm{mg} \mathrm{kg}^{-1}$ and $\mathrm{K}_{2} \mathrm{O} 101-175 \mathrm{mg} \mathrm{kg}^{-1}$, organic carbon $\left(\mathrm{C}_{\text {org }}\right) 1.47 \%$, total nitrogen $\left(\mathrm{N}_{\text {tot }}\right) 0.14$ $0.16 \%$. Alfalfa nursery was established after a black fallow without a cover crop within the first ten-day period of July in 2013. A complex phosphorus (P) and potassium $(\mathrm{K})$ fertiliser was applied once before sowing at a rate of $\mathrm{P}_{60} \mathrm{~K}_{90}$. Each accession was sown at a rate of $0.2 \mathrm{~g}$ scarified seed per 1 meter in two 5-metre long rows in four replications with a special hand-sowing machine Plomatic 1R (Wintersteiger, Austria). The distance between the rows of a line was $0.5 \mathrm{~m}$, between different accessions $-1.0 \mathrm{~m}$. The field area of sowing of one accession was $2.5 \mathrm{~m}^{2}$. The field area of one replication was $2760 \mathrm{~m}^{2}$.

The experimental material included 46 accessions (populations and cultivars) of (Medicago sativa L. and M. varia Marth.) of alfalfa of different geographical origin: 26 accessions from Lithuania, 3 cultivars from Estonia, 1 cultivar - from Latvia, 9 cultivars - from Romania, 4 cultivars - from Czech Republic, 2 cultivars - from Slovakia and 1 - from Poland. Breeding nurseries of alfalfa were assessed in 2014-2017. The breeding nursery was evaluated for spring regrowth (SR), two weeks after resumption of vegetation and after each grass regrowth of the $1^{\text {st }}$ and $2^{\text {nd }}$ cuts $(1 \mathrm{R}$ and $2 \mathrm{R})$, measured plant height $(\mathrm{cm})$, plant height $(\mathrm{PH})$ before flowering $(\mathrm{cm})$ of the $1^{\text {st }}, 2^{\text {nd }}$ and $3^{\text {rd }}$ cuts $(1 \mathrm{PH}, 2 \mathrm{PH}$ and $3 \mathrm{PH})$. The plant height in spring regrowth after resumption of vegetation and before cuts in each treatment plots were measured for 30 plants in four replications. The plants were cut three times in each experimental year at an early flowering growth stage $(10.0 \%$ flowers). For determining dry grass content, fresh samples $(500 \mathrm{~g})$ of randomly chosen plants were taken from each plot, dried at $105^{\circ} \mathrm{C}$ and weighed. Agro-morphological traits: stem density (SD), plant luxuriance (PL), leafiness (L) and stem thickness (ST), were measured on a 1-9 score scale ( 9 being the best value) at flowering time. The agro-morphological traits were estimated by visually scoring each treatment plot in four replications. The seed yield (SY) $\left(\mathrm{kg} \mathrm{ha}^{-1}\right)$, fresh matter and dry grass yield (FMY and DGY) $\left(\mathrm{t} \mathrm{ha}^{-1}\right)$ per year were measured.

Downy mildew (DM) and spring black stem and leaf spot (SBSLS) were evaluated in 2014-2017. Disease severity was evaluated during all season (May-July) by using the scale: $0.0,0.1,1.0,5.0,10.0,20.0,40.0,60.0$ and $80.0 \%$. Resistance to Sclerotinia stem and crown rot (SSCR) was evaluated three weeks after resumption of vegetation. The disease severity was measured on a scale of $0-9$ (were 1 is the lowest value). The following grouping by disease severity scores was used to estimate resistance of accessions: $<3.0$ resistant $(\mathrm{R}),>3.0-4.0$ medium resistant-resistant (MR-R), $>4.0-5.0$ medium resistant (MR), >5.0-6.0 medium susceptible (MS), $>6.0-7.0$ medium susceptible-susceptible (MS-S), >7.0 susceptible (S), >8-9 very susceptible-plant dead (VS$\mathrm{PD})$. The fungal diseases were estimated by visually scoring each treatment plot in four replications.

The area under the disease progress curve (AUDPC) of downy mildew and SBSLS was calculated as the total area the graph of disease severity against time, from the first scoring to the last:

$$
\text { AUDPC }=\mathrm{S}_{\mathrm{i}=1}^{\mathrm{n}-1}\left[\left(\mathrm{t}_{\mathrm{i}+1}-\mathrm{t}_{\mathrm{i}}\right)\left(\mathrm{y}_{\mathrm{i}}+\mathrm{y}_{\mathrm{i}+1}\right) / 2\right] \text {, }
$$

where $t$ is time in day of each reading, $y-$ the percentage of affected foliage at each reading, $\mathrm{n}-$ the number of readings (Simko, Piepho, 2012).

For the assessment of alfalfa-grass mixture's below and above ground phytomass development in a low productivity acidic soil, experiment II was established in 2014 at the Véžaičiai Branch of Lithuanian Research Centre for Agriculture and Forestry (in the western part of Lithuania, $55^{\circ} 70 \mathrm{~N}$ lat., $21^{\circ} 49 \mathrm{E}$ long.). The western region of Lithuania is strongly influenced by 
the maritime climate and is characterized as moderately warm and humid. In comparison with the other regions, the amount of precipitation is the highest there. During the study period, the average air temperature was $-3.1^{\circ} \mathrm{C}$ in January and $+17.6^{\circ} \mathrm{C}$ in July. The average annual precipitation was $986 \mathrm{~mm}$ and ranged between $720 \mathrm{~mm}$ in 2014 and $1276 \mathrm{~mm}$ in 2017 (Table 1).

Table 1. The weather conditions in experiments I and II, 2014-2017

\begin{tabular}{|c|c|c|c|c|c|}
\hline & 2014 & 2015 & 2016 & 2017 & $\mathrm{SCN}$ \\
\hline \multicolumn{6}{|c|}{ Meteorological conditions of experiment I } \\
\hline Annual mean temperature ${ }^{\circ} \mathrm{C}$ & 8.0 & 8.5 & 7.7 & 7.7 & 6.3 \\
\hline Growing season's mean air temperature ${ }^{\circ} \mathrm{C}$ & 14.7 & 14.1 & 14.8 & 13.5 & 11.9 \\
\hline Total annual precipitation $\mathrm{mm}$ & 591 & 503 & 749 & 713 & 816 \\
\hline Growing season's total precipitation $\mathrm{mm}$ & 372 & 257 & 390 & 447 & 495 \\
\hline \multicolumn{6}{|c|}{ Meteorological conditions of experiment II } \\
\hline Annual mean temperature ${ }^{\circ} \mathrm{C}$ & 8.0 & 8.1 & 7.8 & 7.5 & 7.0 \\
\hline Growing season's mean air temperature ${ }^{\circ} \mathrm{C}$ & 13.2 & 11.9 & 11.6 & 12.1 & 12.4 \\
\hline Total annual precipitation $\mathrm{mm}$ & 720 & 914 & 1003 & 1276 & 914 \\
\hline Growing season's total precipitation $\mathrm{mm}$ & 444 & 462 & 617 & 720 & 601 \\
\hline
\end{tabular}

$\mathrm{SCN}$ - the standard climate norm

The soil of the experiment II site was Bathygleyic Dystric Glossic Retisol (WRB, 2014) with a texture of medium heavy loam. Before the experiment establishment in the autumn of 2013, the soil was treated once with dolomitic lime. The content of calcareous material was calculated on the basis of hydrolytic acidity and lime was applied at a rate of $1.0\left(7 \mathrm{tha}^{-1} \mathrm{CaCO}_{3}\right)$. Due to the liming, the soils differed in acidity. The indicators of agrochemical properties of soils in the 0-10 and $10-20 \mathrm{~cm}$ layers at the beginning of the experiment are presented in Table 2.

Table 2. Agrochemical properties of the soil arable layer of experiment II, 2014

\begin{tabular}{|c|c|c|c|c|}
\hline \multirow{2}{*}{ Soil properties } & \multicolumn{2}{|c|}{ Soil pH 3.9} & \multicolumn{2}{|c|}{ Soil pH 5.0} \\
\hline & $0-10 \mathrm{~cm}$ & $10-20 \mathrm{~cm}$ & $0-10 \mathrm{~cm}$ & $10-20 \mathrm{~cm}$ \\
\hline Mobile $\mathrm{Al}^{3+} \mathrm{mg} \mathrm{kg}^{-1}$ & $88.6 \pm 11.73$ & $89.4 \pm 12.58$ & $3.9 \pm 2.22$ & $43.3 \pm 6.95$ \\
\hline Mobile $\mathrm{P}_{2} \mathrm{O}_{5} \mathrm{mg} \mathrm{kg}^{-1}$ & $162.6 \pm 10.33$ & $161.9 \pm 8.88$ & $135.3 \pm 6.49$ & $135.4 \pm 6.96$ \\
\hline Mobile $\mathrm{K}_{2}^{2} \mathrm{O}^{5} \mathrm{mg} \mathrm{kg}^{-1}$ & $201.4 \pm 5.68$ & $200.4 \pm 3.80$ & $195.5 \pm 6.69$ & $192.0 \pm 5.83$ \\
\hline Organic carbon $(\mathrm{C}) \%$ & $1.43 \pm 0.05$ & $1.42 \pm 0.04$ & $1.46 \pm 0.04$ & $1.43 \pm 0.04$ \\
\hline Total nitrogen $\left(\mathrm{N}_{\text {tot }}\right)^{\mathrm{org}} \%$ & $0.13 \pm 0.00$ & $0.13 \pm 0.00$ & $0.13 \pm 0.00$ & $0.14 \pm 0.00$ \\
\hline
\end{tabular}

The mixtures of alfalfa and Poaceae grasses were sown with the cover crop of spring barley cultivar 'Luoke'. The composition of mixtures: alfalfa $50.0 \%$ + timothy-grass $35.0 \%+$ common meadow-grass $15.0 \%$. The alfalfa cultivar 'Birute' chosen for the field experiments was of local origin, productive and winter hardy. Cultivars of perennial grasses and seed rate: alfalfa (Medicago varia Marth.) 'Birutè' - $12 \mathrm{~kg} \mathrm{ha}^{-1}$, timothy-grass (Phleum pratense L.) 'Dubingiai' - $10 \mathrm{~kg}$ $\mathrm{ha}^{-1}$, common meadow grass (Poa pratensis L.) 'Rusne' $-10 \mathrm{~kg} \mathrm{ha}^{-1}$. In the year of grass sowing (2014), the cover crop was fertilised with $\mathrm{N}_{60} \mathrm{P}_{60} \mathrm{~K}_{90}$. The mixture was sown on $26^{\text {th }}$ of May 2014, across the barley rows. Before and after sowing the soil was rolled. Sowing was performed with a seeding machine Saxonia A-201 (VEB Saxonia, Germany). The experiment was established in four replications. The treatments were laid out randomly. The trial field area was $3.0 \times 8.0 \mathrm{~m}=24 \mathrm{~m}^{2}$.

Soil samples for chemical analyses were collected from the $0-10$ and 10-20 cm layers with a drill from each treatment's four replicated plots. Soil agrochemical characteristics were determined by the following methods: the soil $\mathrm{pH}_{\mathrm{KCl}}$ - by potentiometric method in the extraction of $1 \mathrm{M} \mathrm{KCl}$ according to ISO 10390:2005 (Soil quality - Determination of $\mathrm{pH})$; total nitrogen $\left(\mathrm{N}_{\mathrm{tot}}\right)$ content - by the Kjeldahl method; mobile phosphorus $\left(\mathrm{P}_{2} \mathrm{O}_{5}\right)$ and potassium $\left(\mathrm{K}_{2} \mathrm{O}\right)$ - by the Egner-Riehm-Domingo (A-L) method, organic carbon $\left(\mathrm{C}_{\mathrm{org}}\right)$ - by the dry combustion Dumas method, mobile aluminium $\left(\mathrm{Al}^{3+}\right)$ content - by the ISO 14254:2018 (Soil quality - Determination of exchangeable acidity using barium chloride solution as extractant). The dynamics of root and aboveground part (shoot) development was evaluated during alfalfa development stages: on the $27^{\text {th }}$ of June (32 days after sowing $-1-2$ true leaf stage), on the $29^{\text {th }}$ of July (64 days after sowing $-2-6$ true leaf stage), on the $29^{\text {th }}$ of August (94 days after sowing - lateral shoot formation stage) and at the end of vegetation - on the $7^{\text {th }}$ of October (133 days after sowing). At the time of assessment, 20 individual alfalfa plants were excavated from each treatment plot. The length $(\mathrm{cm})$ of fresh plant parts and air-dried mass (g) of the roots and the aboveground part (shoots) were determined. The mass was determined by electronic scales.

Samples of the belowground phytomass (roots) were collected at the end of vegetation. Mass was determined by the quantitative measuring method: the roots were dug in two places of each plot with a cylinder having an area of $78.5 \mathrm{~cm}^{2}$ from the $0-10$ and $10-20 \mathrm{~cm}$ soil layers, washed with running water through a $0.25 \mathrm{~mm}$ mesh, air-dried and weighed (Rosário et al., 2000). The plots were sprayed with the herbicide Basagran 480 (a.i. bentazon $480 \mathrm{~g} \mathrm{l}^{-1}$ ) $21 \mathrm{ha}^{-1}$ when after germination alfalfa had reached the height of $10 \mathrm{~cm}$ in 2013 . The insecticide Mavrik 2F (a.i. tau-fluvalinate $240 \mathrm{~g} \mathrm{l}^{-1}$ ) $0.15-0.201 \mathrm{ha}^{-1}$ was applied when pests had reached harmful levels.

Statistical analysis. The significance of the differences between the experimental treatments was evaluated by the one-factor analysis of variance (ANOVA) (Raudonius, 2017). The years and accessions interaction was evaluated by the two-factor ANOVA. The significance of the differences between the averages was determined by the least significant difference $\left(\mathrm{LSD}_{05}\right)$ with $95 \%$ and $99 \%$ probability levels $(P<0.05$ and $P<0.01)$. All the data presented are the mean values of three independent sets of experiments $( \pm$ standard error, SE).The relationships among the characteristics were evaluated using the correlation-regression analysis method with the statistical program SAS Enterprise Quide, version 7.13 (SAS Institute Inc., USA).

\section{Results and discussion}

Evaluation of development of alfalfa plants in Cambisol. The ANOVA for agro-biological traits is shown in Table 3. The year effect was also highly significant for all the components. 
Table 3. ANOVA of different agro-biological traits of alfalfa plants, 2014-2017

\begin{tabular}{|c|c|c|c|c|c|c|c|}
\hline & \multicolumn{7}{|c|}{ Traits } \\
\hline & df & SSCR & SY & FMY & DGY & ST & SD \\
\hline Acçessions & 45 & $* *$ & $* *$ & $* *$ & $* *$ & $* *$ & $* *$ \\
\hline Year & 3 & $* *$ & $* *$ & $* *$ & $* *$ & $*$ & $*$ \\
\hline Year $\times$ accessions & 135 & $* *$ & $* *$ & $* *$ & $* *$ & $* *$ & ** \\
\hline & \multicolumn{7}{|c|}{ Traits } \\
\hline & df & PL & $\mathrm{L}$ & SR & $1 \mathrm{R}$ & $2 \mathrm{R}$ & $1 \mathrm{PH}$ \\
\hline Accessions & 45 & ** & ** & $*$ & $* *$ & ** & $* *$ \\
\hline Year & 3 & $* *$ & $* *$ & ** & $* *$ & ** & $* *$ \\
\hline & \multicolumn{7}{|c|}{ Traits } \\
\hline & df & $2 \mathrm{PH}$ & $3 \mathrm{PH}$ & $\begin{array}{c}\text { DM II } \\
\text { AUDPC value }\end{array}$ & $\begin{array}{c}\text { SBSLS II } \\
\text { AUDPC value }\end{array}$ & $\begin{array}{c}\text { SBSLS I } \\
\text { AUDPC value } \\
\end{array}$ & $\begin{array}{c}\text { DM I } \\
\text { AUDPC value }\end{array}$ \\
\hline Accessions & 45 & $\begin{array}{l}* * \\
* *\end{array}$ & $\begin{array}{l}* * \\
* *\end{array}$ & $\begin{array}{c}* * \\
* *\end{array}$ & $\begin{array}{l}* * \\
* *\end{array}$ & $* *$ & $* *$ \\
\hline $\begin{array}{c}\text { Year } \\
\text { Year } \times \text { accessions }\end{array}$ & $\begin{array}{c}3 \\
135\end{array}$ & ** & ** & $* *$ & ** & $\begin{array}{l}* \\
* *\end{array}$ & $\begin{array}{l}* \\
* *\end{array}$ \\
\hline
\end{tabular}

SSCR - Sclerotinia stem and crown rot, SY - seed yield, FMY - fresh matter yield, DGY - dry grass yield, ST - stem thickness, $\mathrm{SD}$ - stem density, $\mathrm{PL}$ - plant luxuriance, L - leafiness, SR - spring regrowth; $1 \mathrm{R}, 2 \mathrm{R}$ - grass regrowth after $1^{\text {st }}$ and $2^{\text {nd }}$ cuts, $1 \mathrm{PH}$, $2 \mathrm{PH}, 3 \mathrm{PH}-$ plant height $(\mathrm{PH})$ at flowering stage before $1^{\text {st }}, 2^{\text {nd }}$ and $3^{\text {rd }}$ cuts, AUDPC - the area under the disease progress curve, DM II AUDPC value - downy mildew of grass field, SBSLS II AUDPC value - spring black stem leaf spot of grass field, SBSLS I AUDPC value - spring black stem leaf spot of seed field, DM I AUDPC value - downy mildew of seed field; df - degree of freedom; **, * - significant at 0.05 and 0.01

Significant differences $(P<0.01)$ were determined between alfalfa cultivars and breeding materials in all investigated traits (Fig. 1). The year and accession interaction effect was also highly significant for all components. These interactions showed that accessions of alfalfa significantly differed in resistance to diseases, seed, fresh matter and dry grass yields, morphological traits in all experimental years.
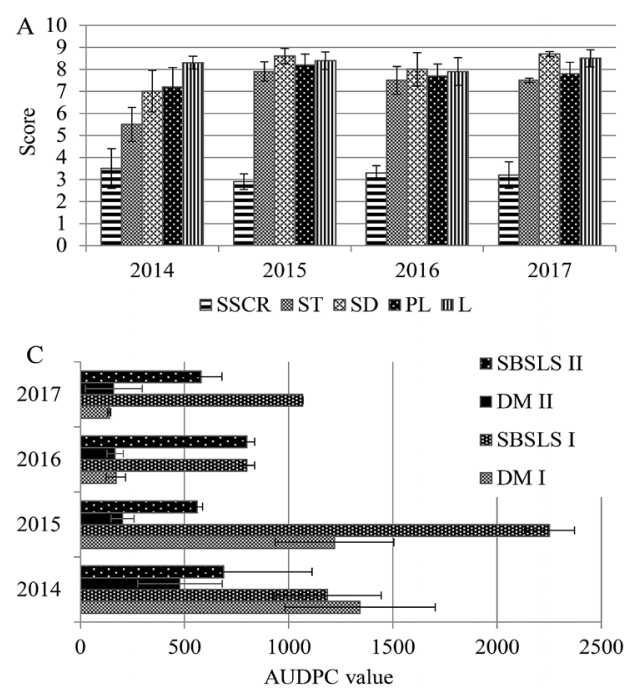

Explanations under Table 3

Figure 1. Average values of agro-biological traits of alfalfa plants

$\left(716.0 \mathrm{~kg} \mathrm{ha}^{-1}\right)$. The dry grass yield and fresh matter yield were similar in all experimental years and ranged 46.3$53.7 \mathrm{t} \mathrm{ha}^{-1}$ and $11.0-13 \mathrm{t} \mathrm{ha}^{-1}$, respectively (Fig. 1B).

According to the average experimental data from four years of variety testing, cultivars from Romania, Lithuania, Estonia and Latvia produced a higher dry grass yield compared with average of all years -1.1 and 1.2 times, respectively. Accessions of alfalfa differed in stem density, plant luxuriance, stem thickness and leafiness (Fig. 1A). Also, accessions of alfalfa significantly differed in regrowth rate during spring, after cuts and plant height at flowering time (Fig. 1D). Cultivars from Czech Republic and Slovakia differed in plant regrowth height during spring and regrowth height after cuts. Cultivars from Lithuania, Czech Republic and Slovakia significantly differed in plant height at flowering time, and plant height of the $1^{\text {st }}$ cut ranged 101.2, 106.2 and $101.7 \mathrm{~cm}$, respectively. SSCR developed very slowly in
The warm and dry weather conditions in 20142015 were more favourable for seed productivity. The seed yield was $312.1 \mathrm{~kg} \mathrm{ha}^{-1}$ in 2014 and $814.6 \mathrm{~kg} \mathrm{ha}^{-1}$ in 2015 (Fig. 1B). According to the average experimental data from four years of variety testing, 'Žydrūnè' produced a higher (1.8 times) seed yield compared with the average seed yield. Therefore, 'Žydrūnè' produced 1.3 times lower seed yield $\left(532.4 \mathrm{~kg} \mathrm{ha}^{-1}\right)$ than 'Skriveru'
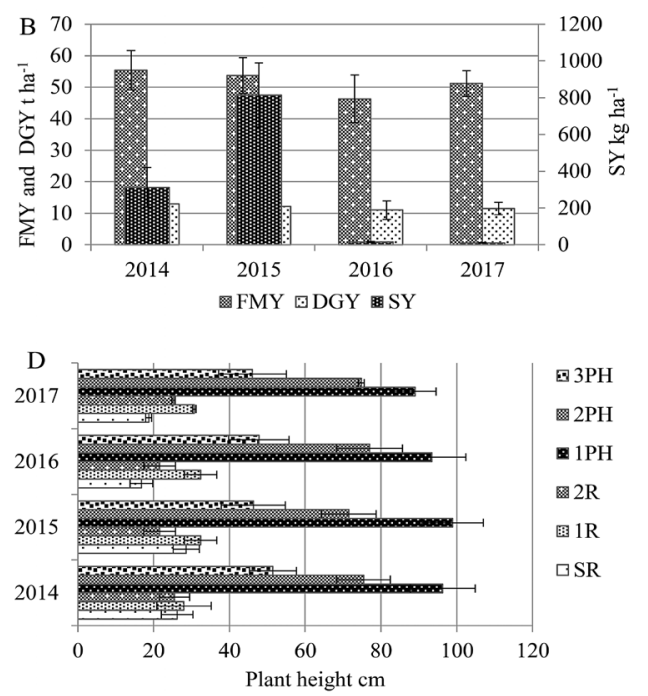

the accessions. Accessions of alfalfa were very resistant to SSCR (ranged 2.9-3.5 score) in all experimental years (Fig. 1A), because the weather conditions were warm and wet during winter period.

SBSLS caused by Phoma medicaginis var. medicaginis is one of the most damaging diseases in Europe (Mrabet et al., 2011; Djebali, 2013). This disease is extremely harmful under the wet cool temperate climate of Lithuania; it alone can destroy whole plant (Rashidi et al., 2009) and all seed yield (Liatukienè, 2012). SBSLS quickly spread during spring-summer period in all experimental years, because the weather conditions of this period were very wet and warm. The accessions of alfalfa distinctly differed by resistance to SBSLS. Cultivars from Lithuania were the least damaged by SBSLS (AUDPC value was 1424.5). Disease development was more or less evenly progressive in the genotypes. AUDPC value was similar during 
2014-2017 period; in seed field (SBSLS I) ranged from 797.6 to 2251.2 and in grass field (SBSLS II) - from 560.3 to 798.2 (Fig. 1C). A broad range of reaction was determined between SBSLS II AUDPC value and other traits (Table 3 ).

The highest positive impact of SBSLS II was found in plant regrowth height after the $1^{\text {st }}$ cut $(r=0.714$, $P<0.01)$. It correlated negatively with fresh matter and dry grass yields $(r=-0.631, P<0.01)$. High positive impact of SBSLS I was found on fresh matter yield $(r=0.706, P<0.01)$, medium positive on dry grass yield and stem thickness $(r=0.696, P<0.01$ and $r=0.629$ $P<0.01$ ). Analysis of correlation of SBSLS AUDPC value with traits showed mainly negative impact of the disease on alfalfa productivity. Some traits that correlated positively can be explained too. Also, positive and negative reactions to Phoma medicaginis were observed in the stem thickness, plant luxuriance and leafiness $(r=0.416, P<0.01, r=-0.477, P<0.01$ and $r=-0.479$, $P<0.01$ ) (Table 4). These observations comply with the data across the world (Rashidi et al., 2009).

Table 4. Correlations between diseases and agro-biological traits of alfalfa plants, 2014-2017

\begin{tabular}{|c|c|c|c|c|c|}
\hline Traits & $\begin{array}{l}\text { SSCR, } \\
\text { score }\end{array}$ & $\begin{array}{c}\text { DM I } \\
\text { AUDPC value }\end{array}$ & $\begin{array}{c}\text { SBSLS I } \\
\text { AUDPC value }\end{array}$ & $\begin{array}{c}\text { DM II } \\
\text { AUDPC value }\end{array}$ & $\begin{array}{c}\text { SBSLS II } \\
\text { AUDPC value }\end{array}$ \\
\hline DM I AUDPC value & $0.486 * *$ & & & & \\
\hline SBSLS I AUDPC value & $-0.422 * *$ & -0.26 & & & \\
\hline DM II AUDPC value & 0.235 & $0.703 * *$ & $-0.564 * *$ & & \\
\hline SBSLS II AUDPC value & 0.086 & $0.451 * *$ & $-0.534 * *$ & $0.869 * *$ & \\
\hline Seed yield (SY) kg ha $\mathrm{kg}^{-1}$ & -0.289 & -0.15 & $0.386^{* *}$ & -0.099 & 0.078 \\
\hline Fresh matter yield (FMY) t ha ${ }^{-1}$ & -0.273 & $-0.326^{*}$ & $0.706 * *$ & $-0.628 * *$ & $-0.631 * *$ \\
\hline Dry grass yield (DGY) $\mathrm{t} \mathrm{ha}^{-1}$ & -0.243 & -0.26 & $0.696 * *$ & $-0.59 * *$ & $-0.631 * *$ \\
\hline Stem thickness (ST), score & $-0.322^{*}$ & $-0.354^{*}$ & $0.629 * *$ & $-0.500 * *$ & $-0.477 * *$ \\
\hline Stem density (SD), score & $-0.543 * *$ & $-0.688 * *$ & 0.133 & $-0.302 *$ & -0.044 \\
\hline Plant luxuriance (PL), score & -0.286 & $-0.653 * *$ & 0.279 & $-0.637 * *$ & $-0.479 * *$ \\
\hline Leafiness (L) score & -0.138 & -0.245 & -0.142 & 0.117 & $0.416^{* *}$ \\
\hline Spring regrowth $(\mathrm{SR}) \mathrm{cm}$ & -0.133 & $0.306^{*}$ & $0.416 * *$ & -0.031 & -0.181 \\
\hline Grass regrowth after $1^{\text {st }} \mathrm{cut}(1 \mathrm{R}) \mathrm{cm}$ & 0.076 & $0.685^{* *}$ & -0.274 & $0.747 * *$ & $0.714 * *$ \\
\hline Grass regrowth after $2^{\text {nd }}$ cut $(2 \mathrm{R}) \mathrm{cm}$ & 0.068 & $0.588 * *$ & 0.025 & $0.383 * *$ & 0.176 \\
\hline $\begin{array}{l}\text { Plant height at flowering stage before } \\
1^{\text {st }} \mathrm{cut}(1 \mathrm{PH}) \mathrm{cm}\end{array}$ & -0.019 & 0.215 & $0.424 * *$ & -0.149 & -0.216 \\
\hline $\begin{array}{l}\text { Plant height at flowering stage before } \\
2^{\text {nd }} \text { cut }(2 \mathrm{PH}) \mathrm{cm}\end{array}$ & 0.082 & $0.512 * *$ & -0.103 & $0.421 * *$ & $0.36^{*}$ \\
\hline $\begin{array}{l}\text { Plant height at flowering stage before } \\
3^{\text {rd }} \mathrm{cut}(3 \mathrm{PH}) \mathrm{cm}\end{array}$ & 0.099 & $0.616 * *$ & 0.048 & $0.356^{*}$ & 0.19 \\
\hline
\end{tabular}

Explanations under Table $3 ; * *$ * - significant at 0.05 and 0.01 level

Downy mildew, caused by Peronospora trifoliorum de Bary, is a harmful disease of alfalfa in the temperate climate areas. One of the specific features of the disease is the ability to overwinter in plants and develop after the beginning of vegetation. Usually it damages the top of the plant. Top damage of plants has highly negative impact on for seed production even under the relatively low disease severity in all susceptible accessions. The most efficient means for disease control is to grow resistant cultivars (Nagl et al., 2011). The downy mildew spread quickly due to cold and rainy weather conditions in spring period in 2014-2015. However, SBSLS developed very quickly in spring and summer period and it was not critical for seed yield in 2014-2015 (Fig. 1C). The weather conditions were very dry and warm in June-August period and were favourable for seed production in 2014-2015. In 2016-2017, the seeds were not produced due to quick spread of SBSLS and weather conditions at flowering time (Fig. 1B). However, the weather conditions were very favourable for downy mildew development. The rapid development of downy mildew was inhibited by SBSLS. The spring-summer period was moderately dry and rainy in 2016, but in 2017 it was very wet.

Previous investigations of alfalfa accessions with diverse geographical origin showed that accessions originating from different regions were more susceptible. Accessions that are more resistant usually originate from regions with similar climate (Kamphuis et al., 2008). In our research it was determined that cultivars from Estonia, Latvia and Lithuania were the least damaged by downy mildew in the grass and seed fields. Downy mildew in seed and grass fields (I and II AUDPC values) moderately negatively and positively influenced agro-morphological traits: stem density, plant luxuriance, fresh matter and dry grass yields, plant height of the $1^{\text {st }}$ and $2^{\text {rd }}$ grass regrowth and plant height at flowering time, before the $2^{\text {nd }}$ and $3^{\text {rd }}$ cuts. Correlation coefficients ranged: $r=0.512, P<0.01$, $r=0.747, P<0.01, r=-0.59, P<0.01$ and $r=-0.688$, $P<0.01$, also the highest positive strong correlations were determined between diseases $(r=0.703, P<0.01$; $r=0.869, P<0.01$ ) (Table 4).

Analysis of correlations of downy mildew I and II AUDPC values with traits showed mainly negative impact of the disease on alfalfa productivity. The results showed that the cultivars of alfalfa significantly differed in agro-biological traits, especially resistance to fungal diseases, fresh matter and dry grass yields. The cultivars of colder climate conditions were more distinguished by resistance to SBSLS and downy mildew, better fresh matter and dry grass yields. The Lithuanian cultivar 'Birutè' showed better resistance to diseases and fresh matter and dry grass yields compared with other cultivars. Cultivar 'Birutè' was similar in agro-biological traits with other Lithuanian cultivars.

Evaluation of development of alfalfa cultivar

'Birute' in Retisol. When evaluating alfalfa as a multifunctional plant, one of the most important tasks was to study the peculiarities of its development in a naturally acidic soil during the sowing year (2014). The development of plants during the sowing year is the main factor determining the productive age of perennial grasses, especially in an acidic soil (Daugëlienè, 2010). In the year of sowing, perennial grasses are sensitive: they grow slowly during the period the root system develops. Franco et al. (2011) points out that a well-developed root system can be beneficial to plant growth and define the plant's ability to absorb water and nutrients. The hybrid Lithuanian alfalfa cultivar 'Birute' chosen for the field experiments was productive and winter hardy in Cambisol (Svirskis, 2002). The growth and development of 'Birute' at different stages depended on the environmental conditions (soil $\mathrm{pH}$, the amount of $\mathrm{Al}^{3+}$ in the soil, meteorological conditions and effect of cover crop). 
In low productivity and acidic soils, the distribution of alfalfa roots in the soil depths depended on soil $\mathrm{pH}, \mathrm{Al}^{3+}$ content and plant age. In the soil with $\mathrm{pH}$ 5.5 , alfalfa emerged 7 days earlier than in the soil with $\mathrm{pH}$ 3.9. Non-adapted to environmental conditions alfalfa individuals disappeared in acidic soil. The roots of alfalfa at 1-2 true leaf stage in the soil with $\mathrm{pH} 5.0$ were 5.4\% shorter and root mass of individual plant was 5.2\% lower compared with alfalfa grown in the naturally acidic soil (Figs 2 and 3).

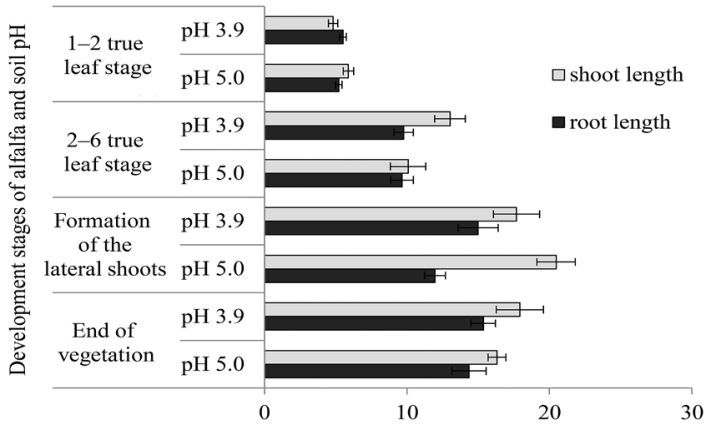

Figure 2. Shoot length and root length $(\mathrm{cm})$ of alfalfa plants in the first year of growth, 2014

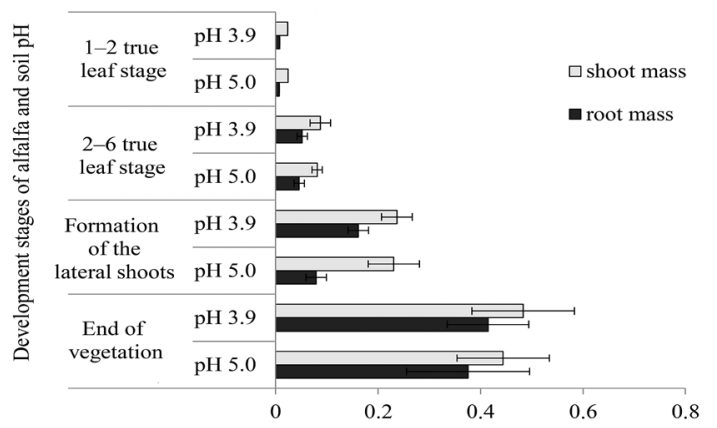

Figure 3. Shoot and root mass (g) of alfalfa plants in the first year of growth, 2014

Literature indicates that if the mineral nutrition is unfavourable, the plants develop longer roots and increase the mass of underground organs in search of nutrients (Holub et al., 2013; Skuodienè et al., 2017). The presence of roots in certain layers is not necessarily equivalent to root activity. The presence of roots shows the potential of the plant access to different soil layers (Hoekstra et al., 2014).

The acidity of soil solution is an important factor having the impact on plant nutrition, fertility and prevalence. Any kind of pollution causes stress for plants. Acid soils increase the solubility of heavy metals and the elution of nutrients (Grantz et al., 2003). However, the height of alfalfa aboveground shoots and their mass were higher in soils, where the nutritional conditions were more favourable. In the soil with $\mathrm{pH} 5.0$ a weak correlation $(r=0.463, P<0.01)$ between plant height and root mass was observed. In both naturally acidic soil and in the soil with $\mathrm{pH} 5.0$, the moderate correlation was determined between shoot height and their mass $(r=0.634, P<0.01$ and $r=0.572, P<0.01$, respectively). During the alfalfa's $2-6$ true leaf stage the soil acidity had no significant influence on root length and mass. During the period from $1-2$ to $2-6$ true leaf stage, in both limed and unlimed soil, the roots of alfalfa grew similarly (Figs 2 and 3). Since spring barley in the acidic soil was very scattered and short, due to lower competition of alfalfa with the cover crop, the height and mass of the aboveground shoots of individual plants were significantly higher $(29.2 \%$ and $7.6 \%)$ in the soil with $\mathrm{pH}$ 3.9 compared to the soil with $\mathrm{pH}$ 5.0.

During the formation of the lateral shoots, alfalfa roots developed vigorously, their mass increased almost twice in the soil with $\mathrm{pH} 5.0$ and 3.1 times in naturally acidic soil. Since meteorological conditions during this period were favourable, the aboveground shoot height increased up to $10.39 \mathrm{~cm}$ in the soil with $\mathrm{pH} 5.0$ and up to $4.67 \mathrm{~cm}$ in naturally acidic soil. The shoot mass was similar in both soils. During this development period, alfalfa morphological parameters closely correlated with each other (Table 5).

At the end of vegetation, when the roots of alfalfa had reached a layer of soil below $10 \mathrm{~cm}$ in naturally acidic soil, adverse growth conditions were determined due to higher amount of $\mathrm{Al}^{3+}$ (Table 2). In the soil with more favourable nutrition conditions, alfalfa roots increased by $20.0 \%$; however, in the naturally acidic soil the roots increased by only $2.5 \%$ because of high $\mathrm{Al}^{+3}$ concentration $\left(89.44 \mathrm{mg} \mathrm{kg}^{-1}\right)$ at a depth of $10-20 \mathrm{~cm}$. The literature states that the toxicity of $\mathrm{Al}^{+3}$ is recognized as a limiting factor of plant productivity in acidic soils (Čop, 2014; Repšienè, Karčauskienè, 2016). Despite that, the height and mass of aboveground shoots of alfalfa's individual plants changed insignificantly. Statistically significant correlations between morphological parameters were established (Table 4).

The correct selection of Poaceae grass for the mixture determines the productivity of alfalfa, as alfalfa is a slowly developing plant. In the year of sowing of alfalfa-grass mixture (2014), the root mass, diameter and total length were influenced by the soil $\mathrm{pH}$. The highest root mass and total root length was determined when the soil pH was 3.9 (Fig. 4, Table 6).

When the nutrition conditions were more favourable (in the soil with $\mathrm{pH} 5.0$ and low $\mathrm{Al}^{3+}$ content) (Table 2), the root mass in the $0-10$ and $10-20 \mathrm{~cm}$ soil depth was 2.3 times smaller (Fig. 4), and the total root length was 1.2 and 1.4 times smaller compared to the soil with $\mathrm{pH} 3.9$ (Table 6). Alfalfa-grass mixture's root diameter in naturally acidic soil was found to be substantially lower: by $17.2 \%$ and $37.6 \%$ in the $0-10$ and 10-20 cm soil depth, respectively, when compared to the soil with $\mathrm{pH}$ 5.0. It is likely that in the year of sowing, the growth of alfalfa roots in the soil with $\mathrm{pH}$ 3.9 was influenced by toxic $\mathrm{Al}^{3+}$; the roots affected by it were thickened and short. Valle et al. (2009) indicate that higher concentrations of soil $\mathrm{Al}^{3+}$ will result in abnormal growth of crops. During the second year, alfalfa-grass mixture's root development was intense (Fig. 4).

The roots developed and grew faster in the soil with $\mathrm{pH}$ 5.0. Compared to the first year, in naturally acidic soil the total root mass increased by 4.0 times and in the soil with $\mathrm{pH} 5.0$ - by 11.7 times. It was influenced

Table 5. Correlations between the morphological parameters of alfalfa plants

\begin{tabular}{ccccccc}
\hline \multirow{2}{*}{ Soil pH } & \multicolumn{7}{c}{ Correlations between: } \\
\cline { 2 - 7 } & RL and RM & RL and SH & RL and SM & RM and SH & RM and SM & SH and SM \\
\hline pH 5.0 & \multicolumn{7}{c}{ Period of formation of the lateral shoots } \\
\hline pH 3.9 & 0.298 & $0.480^{*}$ & 0.325 & $0.520^{*}$ & $0.614^{* *}$ & $0.619^{* *}$ \\
\hline pH 5.0 & $0.534^{*}$ & $0.675^{* *}$ & 0.362 & $0.710^{* *}$ & $0.503^{*}$ & $0.558^{*}$ \\
pH 3.9 & $0.783^{* *}$ & 0.372 & $0.674^{* *}$ & 0.353 & $0.912^{* *}$ & $0.502^{*}$ \\
\hline
\end{tabular}

$\mathrm{RL}$ - root length, RM - root mass, SH - shoot height, SM - shoot mass; * and ** - significant at 0.05 and 0.01 level 


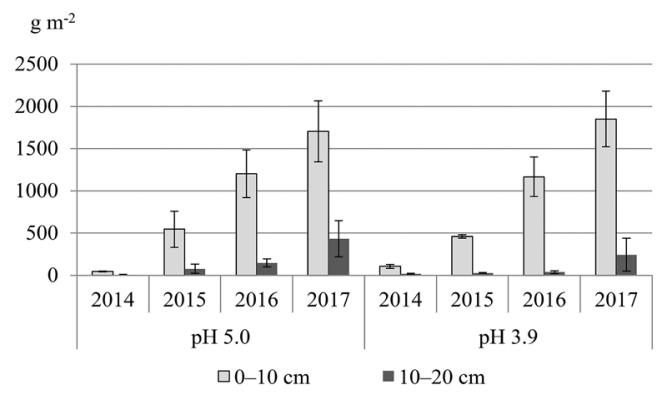

Figure 4. Dynamics of development and growth of alfalfa-grass mixture roots by the change in the composition of mixture in naturally acidic soils: Poaceae grasses (timothy-grass and common meadow-grass) firmly established in the place of vanished alfalfa. In the third year of alfalfa growth, in naturally highly acidic soil only $9.1 \%$ of alfalfa plants remained. A strong correlation $(r=0.873, P<0.01)$ between the amount of alfalfa in the dry grass yield and the soil acidity was determined. During the third and fourth years, when the sward was completely formed, the total root mass in the soil of different acidity increased similarly: 2.2 and 2.5 times in 2016, and 1.6 and 1.7 times in 2017, respectively. The greatest share of alfalfa-grass mixture's root mass (80-97\% of the total root mass at the $0-20 \mathrm{~cm}$

Table 6. Root diameter and total length of alfalfa-grass mixture in the first year of growth, 2014

\begin{tabular}{|c|c|c|c|c|}
\hline \multirow{2}{*}{ Soil pH } & \multicolumn{2}{|c|}{ Root diameter $\mathrm{mm}$} & \multicolumn{2}{|c|}{ Total root length $\mathrm{km} \mathrm{m}^{-2}$} \\
\hline & $0-10 \mathrm{~cm}$ & $10-20 \mathrm{~cm}$ & $0-10 \mathrm{~cm}$ & $10-20 \mathrm{~cm}$ \\
\hline $\mathrm{pH} 5.0$ & 1.102 & 0.776 & 0.318 & 0.071 \\
\hline $\mathrm{pH} 3.9$ & $1.291^{* *}$ & $1.068^{*}$ & 0.482 & 0.147 \\
\hline $\mathrm{LSD}_{05}$ & 0.1430 & 0.2350 & 0.2990 & 0.2090 \\
\hline
\end{tabular}

* and ** - significant at 0.05 and 0.01 level

depth) was accumulated at the $0-10 \mathrm{~cm}$ depth. Root distribution in the soil depended on the soil $\mathrm{pH}$ and $\mathrm{Al}^{3+}$ amount as well as the grassland age. In the first year of grassland growth, irrespective of the soil $\mathrm{pH}, 86.8 \%$ of the root mass was accumulated at the $0-10 \mathrm{~cm}$ depth and $13.2 \%$ - at the $10-20 \mathrm{~cm}$ depth. From the second year of growth, the root mass at the $10-20 \mathrm{~cm}$ depth was greater when the nutrition conditions were more favourable (when the soil pH was 5.0).

\section{Conclusions}

1. The crops of alfalfa (Medicago sativa L. and $M$. varia Marth.) were very productive in terms of fresh matter and dry grass yields: 51.6 and $11.9 \mathrm{t} \mathrm{ha}^{-1}$, respectively. In Cambisol, alfalfa plants stood out by the agro-biological traits: stem density, stem thickness and leafiness in all experimental years. The average seed yield of alfalfa was $814.6 \mathrm{~kg} \mathrm{ha}^{-1}$ in a very dry year. Downy mildew spread more rapidly in the spring period. Therefore, spring black stem and leaf spot (SBSLS) spread quickly in seed and grass crops in the warm and wet period of vegetation in all experimental years.

2. Growth and development of the alfalfa cultivar 'Birutè' at different stages depended on the environmental conditions: soil $\mathrm{pH}$, the content of $\mathrm{Al}^{3+}$ in the soil, meteorological conditions and effect of cover crop. In the sowing year (2014), in the low productivity and naturally acidic soil (Retisol), where the mineral nutrition was unfavourable, 'Birutè' produced longer roots, their diameter and mass were also larger than in the soil with $\mathrm{pH}$ 5.0. In the second year, alfalfa-grass mixture's roots developed rapidly: in the naturally acidic soil the root mass was 4.0 times and in the soil with $\mathrm{pH} 5.0$ - 11.7 times greater than in the first year sward. During the third and fourth years, when the sward was completely formed, the total root mass in the soil of different acidity increased similarly: 2.3 times in the third year and 1.6 times in the fourth year.

\section{Acknowledgments}

The paper presents research findings, obtained through the long-term research programmes "Genetic and purposeful change of genotypes of agricultural and forest plants" and "Productivity and sustainability of agricultural and forestry soils" implemented by Lithuanian Research Centre for Agriculture and Forestry.

\section{References}

1. Annicchiarico P., Pagnotta M. A. 2012. Agronomic value and adaptation across climatically contrasting environments of Italian red clover landraces and natural populations. Grass Forage Science, 67: 597-605.

https://doi.org/10.1111/j.1365-2494.2012.00887.x

2. Avci M., Cinar S., Yucel C., Inal I. 2010. Evaluation of some alfalfa (Medicago sativa L.) lines for herbage yield and forage quality. Journal of Food Agriculture and Environmental, 8: 545-549.

3. Bouton J. H. 2012. Breeding lucerne for persistence. Crop Pasture Science, 63 (2): 95-106. https://doi.org/10.1071/CP12009

4. Čop J. 2014. Soil acidification and liming in grassland production and grassland soil fertility in Slovenia. Acta Agriculturae Slovenica, 103 (1): 15-25 https://doi.org/10.14720/aas.2014.103.1.02

5. Daugèlienè N. 2010. Grassland ecological systems. Lithuanian University of Agriculture, 319 p. (in Lithuanian).

6. Djebali N. 2013. Aggressiveness and host range of Phoma medicaginis isolated from Medicago species growing in Tunisia. Phytopathologia Mediterranea, 52: 3-15.

7. Dugalić G., Gajić B., Bokan N. Jelić M., Tomić Z. Dragović R. 2012. Liming increases alfalfa yield and crude protein content in an acidic silty loam soil. African Journal of Biotechnology, 11: 11552-11558. https://doi.org/10.5897/AJB12.811

8. Filiz V., Meral Ü. 2007. Aluminium toxicity and resistance in higher plants. Advances in Molecular Biology, (1): 1-12. www.advmolbiol.org

9. Franco J.A., Bañón S, Vicente M. J., Miralles J, MartínezSánchez J. J. 2011. Root development in horticultural plants grown under abiotic stress conditions - a review. Journal of Horticultural Science and Biotechnology, 86 (6): 543-556. https://doi.org/10.1080/14620316.2011.11512802

10. Goulding K. W.T.2016. Soil acidification and the importance of liming agricultural soils with particular reference to the United Kingdom. Soil Use and Management, 32 (3): 390 399. https://doi.org/10.1111/sum. 12270

11. Grantz D. A., Garner J. H. B., Johnson D. W. 2003. Ecological effects of particulate matter. Environment International, 29 (2-3): 213-219. https://doi.org/10.1016/S0160-4120(02)00181-2

12. Hoekstra N. J., Finn J. A., Hofer D., Suter M., Lüscher A. 2014. The effect of drought on the depth of water uptake of deep- and shallow-rooting grassland species. EGF at 50: The future of European grasslands. Proceedings of the $25^{\text {th }}$ general meeting of the European Grassland Federation, p. 109-111.

13. Holub P., Tůma I., Fiala K. 2013. Effect of fertilization on root growth in the wet submontane meadow. Plant, Soil and Environment, 59 (8): 342-34. https://doi.org/10.17221/162/2013-PSE

14. Huang B., Eissenstat D. M. 2013. Root plasticity in exploiting water and nutrient heterogeneity. Wilkinson E. (ed.). Plant-Environmental Interactions, 111-132 p.

15. Kamphuis L. G., Lichtenzveig J., Oliver R. P., Ellwood S. R. 2008. Two alternative recessive quantitative trait loci influnce resistance to spring black stem and leaf spot in Medicago truncatula. BMC Plant Biology, 8 (1): 30. https://doi.org/10.1186/1471-2229-8-30 
16. Liatukienè A. 2012. Investigation of genetic diversity of lucerne (Medicago spp.) by identifying resistance to pathogen and mobile aluminium: $\mathrm{PhD}$ dissertation. Lithuanian Research Centre for Agriculture and Forestry, $120 \mathrm{p}$.

17. Marshall A. H., Lowe M., Sizer-Coverdale E. 2014. Root architecture of interspecific hybrids between Trifolium repens L. and Trifolium ambiguum M. Bieb. and their potential to deliver ecosystem services. EGF at 50: The future of European grasslands. Proceedings of the $25^{\text {th }}$ General Meeting of the European Grassland Federation, p. 350-352.

18. Morsy K. M., Abdel-Moniam M. F., Mazen M. M. 2011 Use of abiotic and biotic inducers in controlling fungal diseases and improving growth in alfalfa. Australian Journal of Basic and Applied Sciences, 5 (9): 816-824.

19. Mrabet M., Abdellatif E., Zribi K., Mhamdi R., Djebali N. 2011. Sinorhizobium meliloti can protect Medicago truncatula from infection by Phoma medicaginis. Phytopathologia Mediterranea, 50 (2): 183-191.

20. Nagl N., Ajdukovic K. T., Barac G., Baburski A., Seccareccia I., Milic D., Katic S. 2011. Estimation of genetic diversity in tetraploid alfalfa populations based on RAPD markers for breeding purposes. International Journal Molecular Sciences. Sciences, 12: 5449-5460. https://doi.org/10.3390/ijms12085449

21. Rahman M. A., Lee S.-H., Ji H. C., Kabir A. H., Jones C. S., Lee K.-Won. 2018. Importance of mineral nutrition for mitigating aluminum toxicity in plants on acidic soils: current status and opportunities. International Journal of Molecular Sciences, 19 (10): 1-28. https://doi.org/10.3390/ijms19103073

22. Rashidi M., Zand B., Gholami M. 2009. Effect of different seedling rates on seed yield and some seed yield components of alfalfa (Medicago sativa). International Journal of Agriculture and Biology, 11 (6): 779-782.

23. Raudonius S.2017. Application of statistics in plant and crop research: important issues. Zemdirbyste-Agriculture, 104 (4): 377-382. https://doi.org/10.13080/z-a.2017.104.048

24. Repšienè R., Karčauskienè D. 2016. Changes in the chemical properties of acid soil and aggregate stability in the whole profile under long-term management history. Acta Agriculturae Scandinavica, Section B: Soil and Plant Science, 66 (8): 671-676.

https://doi.org/10.1080/09064710.2016.1200130
25. Rosário M. G. O., van Noordwijk M., Gaze S. R., Brouwer G., Bona S., Mosca G., Hairiah K. 2000. Chapter 6. Auger sampling, ingrowth cores and pinboard methods. Root methods. A handbook. Springer, p. 175-210. https://doi.org/10.1007/978-3-662-04188-8 6

26. Sabanci C. O., Ertus M. M., Zorer Cēebi S. 2013. Collection, conservation and evaluation for forage yield of alfalfa landraces grown in East Anatolia. Turkish Journal of Field Crops, 18 (1): 46-51.

27. Simko I., Piepho H.-P. 2012. The area under the disease progress stairs: calculation, advantage, and application. Analytical and Theoretical Plant Pathology, 102 (4): 381389. https://doi.org/10.1094/PHYTO-07-11-0216

28. Skuodienè R., Tomchuk D., Aleinikovienè J. 2017. Plant root morphology and soil biological indicators under primary development of various swards. Acta Agriculturae Scandinavica, Section B: Plant Soil Science, 67 (5): 435443. https://doi.org/10.1080/09064710.2017.1293724

29. Svirskis A. 2002. Improving of Lucerne productivity by means of breeding Zemdirbyste-Agriculture, 78 (2): 149-157.

30. Tomchuk D. 2018. Grassland belowground biomass and organic carbon accumulation in different terrain ecosystems: doctoral dissertation. Lithuanian Research Centre for Agriculture and Forestry, $132 \mathrm{p}$.

31. Tucak M., Popović S. Čupić T. Krizmanić G. Španić V. Simić B., Megalič V. 2014. Agro-morphological and forage quality traits of selected alfalfa populations and their application in breeding. Turkish Journal of Field Crops, 19 (1): 79-83. https://doi.org/10.17557/tjfc.43607

32. Valle S. R., Carrasco J., Pinochet D., Calderini D. F. 2009. Grain yield, above-ground and root biomass of Altolerant and Al-sensitive wheat cultivars under different soil aluminum concentrations at field conditions. Plant and Soil, 318 (1-2): 299-310.

https://doi.org/10.1007/s11104-008-9841-8

33. Wang S., Ren X., Huang B., Wang G., Zhou P., An Y. 2016. Aluminium-induced reduction of plant growth in alfalfa (Medicago sativa) is mediated by interrupting auxin transport and accumulation in roots. Scientific Reports, 6: 1-13. https://doi.org/10.1038/srep30079

34. WRB. 2014. World reference base for soil resources 2014. World Soil Resources Reports No. 106. FAO, p. 187-189.

35. Zeinab M. A. E.-N., Azzam C. R., Saieda S. A. El.-R. 2014. Evaluation of ten alfalfa populations for forage yield, protein content, susceptibility to seedling damping-off disease and associated biochemical markers with levels of resistance. Journal of American Science, 10 (7): 73-85.

ISSN 1392-3196 / e-ISSN 2335-8947

Zemdirbyste-Agriculture, vol. 107, No. 1 (2020), p. 41-48

DOI $10.13080 /$ z-a.2020.107.006

\title{
Medicago sativa ir M. varia augalų agrobiologinių požymių ivertinimas rudžemyje ir balkšvažemyje
}

\author{
A. Liatukiené1, R. Skuodienè $\dot{e}^{2}$, D. Tomchuk ${ }^{2}$, V. Danyte் ${ }^{1}$ \\ ${ }^{1}$ Lietuvos agrarinių ir miškų mokslų centro Žemdirbystés institutas \\ ${ }^{2}$ Lietuvos agrarinių ir miškų mokslų centro Véžaičių filialas
}

\section{Santrauka}

Liucernos yra reikšmingas žemės ūkio augalas, stabilizuojantis ekosistemą, gerinantis dirvožemio fizikines, chemines ir biologines savybes. Tačiau joms augti tinkamų dirvožemių yra nedaug. Tyrimo tikslas - įvertinti liucernos (Medicago spp.) agrobiologinius rodiklius skirtingomis aplinkos sąlygomis.

Lauko eksperimentai buvo atlikti dviejuose regionuose, taikant optimalią priežiūrą. Produktyviame dirvožemyje (vidutinio sunkumo priemolio rudžemyje) buvo vertinti 46 skirtingos kilmès liucernos (Medicago sativa L. and M. varia Marth.) pavyzdžiai. Aplinkos sąlygos buvo palankios liucernoms augti ir vystytis. Nustatyta, kad tirti liucernos pavyzdžiai esmingai išsiskyrè agrobiologiniais požymiais: augalu aukščiu pavasarinio atžèlimo metu, po pjūčių bei žydejjimo metų ir sẻklų derliumi. Netikroji miltligė mažiausiai pažeidė vésesnio klimato šalių (Estijos, Latvijos ir Lietuvos) augalu veisles. Mažiau derlingame rūgščiame nepasotintajame balkšvažemyje rūgštumas turejjo didelę ịtaką liucernų šaknų sistemos pasiskirstymui. Pirmaisiais jų auginimo metais natūraliai rūgščiame ( $\mathrm{pH}$ 3,9) balkšvažemyje, kai mineralinè mityba buvo nepakankama, išaugo ilgesnès šaknys, ju skersmuo ir masė buvo didesnè, lyginant su rudžemiu, kurio $\mathrm{pH}$ buvo 5,0. Trečiaisiais auginimo metais natūraliai rūgščiame balkšvažemyje liko tik $9,1 \%$ liucernų augalų. Nustatyta stipri koreliacija $(r=0,873, P<0.01)$ tarp liucernų kiekio, sausujjų medžiagų derliaus ir dirvožemio rūgštumo.

Reikšminiai žodžiai: agrobiologiniai požymiai, ligos, liucerna, skirtingo produktyvumo dirvožemiai. 